\title{
Metal-DNA/RNA interaction
}

\section{P451}

\section{Studies on planaramineplatinum(II) complexes with trans-geometry} Fehmida Fasim ${ }^{1}$, Fazlul Huq ${ }^{1}$, Jun Q Yu ${ }^{1}$, Philip Beale ${ }^{2}$ ${ }^{1}$ Discipline of Biomedical Science, Faculty of Medicine, The University of Sydney, Lidcombe, Sydney, NSW 2141, Australia. ${ }^{2}$ Sydney Cancer Centre, Concord Hospital, Sydney, NSW 2139, Australia. ffas9856@mail.usyd.edu.au

Cisplatin is one of the most frequently used chemotherapeutics in the treatment of malignant tumors. Nevertheless, its clinical application is limited due to toxicity, narrow range of activity and low aqueous solubility. Therefore much attention has been focused on the development of new platinums with improved pharmacological properties. Because of low solubility in water, trans-planaramineplatinum(II) complexes with the chloride leaving groups are found to have low bioavailability and hence low in vivo activity. This study aims to replace the chloride leaving groups in selected trans-planaramineplatinum(II) complexes designed in our laboratory namely $\mathrm{YH} 12, \mathrm{CH} 1$ and $\mathrm{CH} 4$ with acetate, formate, trifluoroacetate and hydroxyacetate in order to increase water solubility and bioavailability. To achieve the conversion, essentially the compounds in chloride form are reacted with silver acetate, silver trifluoroacetate, silver formate or silver hydroxyacetate. MTT reduction assay is employed to determine the activity of the compounds in ovarian cancer cell lines A2780, A2780 ${ }^{\text {cisR }}$ and A2780 ${ }^{\text {ZD047R }}$. Results show that although the compounds in the acetate form are indeed more soluble in water, they have lower activity than in the chloride form. It has not been possible to achieve conversion to the formate form due to spontaneous redox reaction between formate and $\mathrm{Pt}^{2+}$ and $\mathrm{Ag}^{+}$ions. Further work is in progress.

\section{P452}

Studies on new polynuclear platinum compounds Shahnaz Al Qassab ${ }^{1}$, Fazlul Huq, Phlip Beale ${ }^{2}$, Jun Q Yu ${ }^{1}$ ${ }^{1}$ Discipline of Biomedical Science, Faculty of Medicine, The University of Sydney, Lidcombe, Sydney, NSW 2141, Australia. ${ }^{2}$ Sydney Cancer Centre, Concord Hospital, Sydney, NSW 2139, Australia.sha13009@mail.usyd.edu.au

Trinuclear compounds such as BBR3464 and $\mathrm{DH}_{6} \mathrm{Cl}$ offer a novel class of platinum compounds with multiple metal centres in a trans-geometry, that are highly active against both cisplatin-responsive and cisplatin-resistant cancer cell lines. However, the compounds are subject to significant breakdown due to the trans-labilizing effect before binding with DNA. It is believed that the corresponding complexes with a cis-geometry for the terminal metal centres would be less subject to such breakdown. The aim of current study is to synthesize new trinuclear Pt complexes having a cis-geometry for the terminal metal centers, determine their activity against ovarian cancer cell lines and nature of binding with DNA. The compounds code named QH1, $\mathrm{QH} 4$ and QH5 have the general formula: $\left[\left\{\text { cis-PtCl}\left(\mathrm{NH}_{3}\right)_{2}\right\}_{2} \mu-\{\right.$ trans$\mathrm{Pt}$ (3-ydroxypyridine $\left.\left.)_{2}\left(\mathrm{H}_{2} \mathrm{~N}\left(\mathrm{CH}_{2}\right)_{n} \mathrm{NH}_{2}\right)_{2}\right\}\right] \mathrm{Cl}_{4}$ where $n=6$ for QH1, $n=4$ for $\mathrm{QH} 4$ and $n=5$ for QH5. The compounds code named QH7 and QH8 have the general formula: $\left[\left\{\text { cis- } \mathrm{PtCl}\left(\mathrm{NH}_{3}\right)_{2}\right\}_{2} \mu-\{\right.$ trans- $\mathrm{Pt}(3-$ hydroxypyridine) $\left.\left.\left(\mathrm{NH}_{3}\right)\left(\mathrm{H}_{2} \mathrm{~N}\left(\mathrm{CH}_{2}\right)_{n} \mathrm{NH}_{2}\right)_{2}\right\}\right] \mathrm{Cl}_{4}$ where $n=6$ for $\mathrm{QH} 7$ and 4 for $\mathrm{QH} 8$. The $\mathrm{IC}_{50}$ values show that $\mathrm{QH} 1$ and $\mathrm{QH} 5$ are significantly more active than cisplatin. The higher activity of QH1 and QH5 in resistant cell lines indicates that the compounds have been able to overcome mechanisms of resistance operating in the cell lines.

\section{P453}

The sequence-dependent stability of 1,3-GNG intrastrand crosslinks of transplatin in double-helical DNA

Jana Kasparkova ${ }^{1,2}$, Victoria Marini ${ }^{1}$, Vendula Bursova ${ }^{1}$, Viktor Brabec ${ }^{1,2}$

${ }^{1}$ Institute of Biophysics, Academy of Sciences of the Czech Republic, CZ-61265 Brno, Czech Republic. ${ }^{2}$ Laboratory of Biophysics, Department of Experimental Physics, Faculty of Sciences, Palacky University, CZ-77146 Olomouc, Czech Republic. jana@ibp.cz

Clinically ineffective transplatin [trans-diamminedichloridoplatinum(II)] is used in the studies of the structure-pharmacological activity relationship of platinum compounds. In addition, a number of transplatin analogs exhibit promising toxic effects in several tumor cell lines including those resistant to conventional antitumor cisplatin. Moreover, transplatin-modified oligonucleotides have been shown to be effective modulators of gene expression. Owing to these facts and because DNA is also considered the major pharmacological target of platinum complexes, interactions between transplatin and DNA are of great interest. We examined, using biophysical and biochemical methods, the stability of $1,3-\mathrm{GNG}$ intrastrand crosslinks (CLs) formed by transplatin in short synthetic oligodeoxyribonucleotide duplexes and natural double-helical DNA. We have found [1] that transplatin forms in double-helical DNA 1,3-GNG intrastrand CLs, but their stability depends on the sequence context. In some sequences the 1,3-GNG intrastrand CLs formed by transplatin in double-helical DNA readily rearrange into interstrand CLs. On the other hand, in a number of other sequences these intrastrand CLs are relatively stable. We show that the stability of 1,3-GNG intrastrand CLs of transplatin correlates with the extent of conformational distortion and thermodynamic destabilization induced in double-helical DNA by this adduct.

\section{Reference}

1. Kasparkova J, Marini V, Bursova V, Brabec V (2008) Biophys J 95:4361-4371

\section{P454}

Synthesis, critical micelle concentration (CMC) determination, DNA binding ability, antimicrobial and anti-tumor activities of surfactant-cobalt(III) complexes: hydrophobic effect

N. Kumaraguru, N. Thajuddin 
Department of Microbiology, Bharathidasan University, Tiruchirappalli, 620 024, India.nkkumaru@yahoo.com Surface active micelle formable Surfactant-Cobalt(III) complexes, cis- $\left[\mathrm{Co}(\text { phen })_{2} \mathrm{DACl}\right]^{2+}$ and cis- $\left[\mathrm{Co}(\text { phen })_{2} \mathrm{DA}_{2}\right]^{3+}$, where $\mathrm{DA}=$ Dodecylamine and Phen $=1,10$-Phenanthroline have been synthesized and characterized. The critical micelle concentration (CMC) values of these complexes in aqueous solution were obtained from conductance measurements. The specific conductivity data (at 303, 308 and $313 \mathrm{~K}$ ) served for the evaluation of the temperature dependent $\mathrm{CMC}$ and the thermodynamics of micellization $\left(\Delta \mathrm{G}_{\mathrm{mic}}^{0}, \Delta \mathrm{H}_{\mathrm{mic}}^{0}\right.$, $\Delta \mathrm{S}_{\text {mic }}^{0}$ ). The interaction between surfactant-cobalt(III) complexes and calf thymus DNA in aqueous solution was investigated by spectroscopic methods, viscosity, cyclic voltammetry and electrophoresis measurements. Results suggest that the two complexes can bind to DNA via intercalation binding, van der Waals interactions and/or electrostatic interactions. The complexes showed moderate antibacterial and antifungal activities against certain selected microorganisms. The anti-tumor activity of complexes on ME-180 human cervical cancer cells was determined adopting MTT assay and specific staining techniques.

\section{References}

1. Kumaraguru N, Santhakumar K, Arunachalam S, Arumugham MN (2006) Polyhedron 25:3253-3260

2. Liu J, Zhang H, Chen C, Deng H, Lu T, Ji L (2003) Dalton Trans 114-119

\section{P455}

Dipolar ruthenium(II)-ammine complexes with $4,4^{\prime}$ bipyridinium: studies on DNA-binding properties and photocleavage activity

Yasuo Nakabayashi, Hitomi Nakamura, Shizuka Izumi, and Osamu Yamauchi

Department of Chemistry and Materials Engineering, Faculty of Chemistry, Materials and Bioengineering, Kansai University, Osaka 564-8680, Japan. yasuon@ipcku.kansai-u.ac.jp

Oxygen is necessary for the typical photodynamic therapy (PDT) drugs to function. This oxygen requirement represents a drawback, since many malignant cancer cells are often hypoxic. A requirement of a potential PDT agent is low cytotoxicity in the dark and increases toxicity upon irradiation. In this study, we examined DNA-binding properties of the dipolar ruthenium(II)-ammine complexes with 4,4'-bipyridinium (Fig. 1) and $f$ X174 RF I DNA photocleavage by these complexes under air and Ar. All the ruthenium(II) complexes show intense and broad MLCT bands in the region 580-677 nm (log $e: 4.18-4.27)$. All the MLCT bands exhibit significant red shifts (29$40 \mathrm{~nm})$ at $[\mathrm{CT}-\mathrm{DNA}] /[\mathrm{Ru}]$ ratio of 10 , suggesting that the corresponding ruthenium(II) complexes involve stacking interactions of $4,4^{\prime}$-bipyridinium with the base-pairs of DNA duplex. Although the more efficient DNA photocleavage is observed under air, the amount

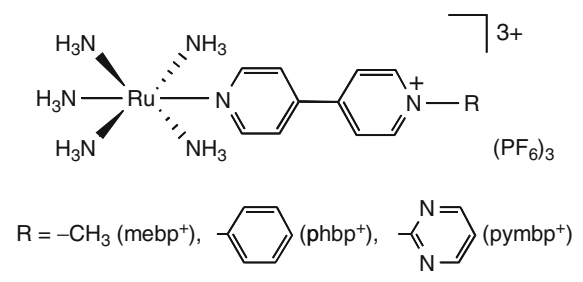

Fig. 1 Ruthenium(II) complexes used in this study
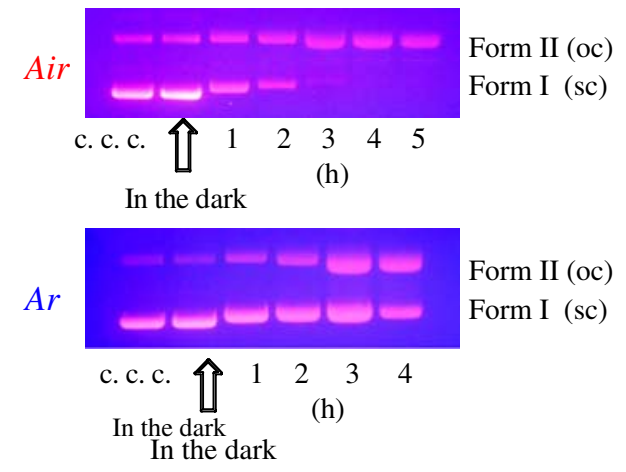

Fig. 2

of Form II (oc) gradually increases with increasing the irradiation time under $\mathrm{Ar}$ (Fig. 2). It is consequently suggested that these complexes function as the oxygen-independent photochemotherapeutic agents.

\section{P456}

\section{Xanthosine 5'-monophosphate:}

\section{an ambivalent nucleotide}

Helmut Sigel

Department of Chemistry, Inorganic Chemistry, University of Basel, Spitalstrasse 51, 4056 Basel, Switzerland.Helmut.Sigel@unibas.ch The four acidity constants of threefold protonated xanthosine $5^{\prime}$ monophosphate, $\mathrm{H}_{3}(\mathrm{XMP})^{+}$, reveal that at the physiological $\mathrm{pH}$ of about $7.5(\mathrm{X}-\mathrm{H} \cdot \mathrm{MP})^{3-}$ strongly dominates and not $\mathrm{XMP}^{2-}$ as given in most textbooks (in analogy to guanosine $5^{\prime}$-monophosphate, GMP ${ }^{2-}$ ) and often assumed in research.

$\mathrm{XMP}^{2-}$ is a minority species (about 12\%), the dominating tautomer being $(\mathrm{X}-\mathrm{H} \cdot \mathrm{MP} \cdot \mathrm{H})^{2-}(\mathrm{ca} 88 \%)$ with a monodeprotonated xanthine residue and a $\mathrm{PO}_{3} \mathrm{H}^{-}$group. In 9-methylxanthine deprotonation occurs to over $99 \%$ at $(\mathrm{N} 3) \mathrm{H}$; in xanthosinate already about $30 \%$ are $(\mathrm{N} 1) \mathrm{H}$ deprotonated and for $(\mathrm{X}-\mathrm{H} \cdot \mathrm{MP})^{3-}$ it is concluded that $(\mathrm{N} 1) \mathrm{H}$ deprotonation is further favored, especially upon $\mathrm{M}^{2+}$ coordination at N7. Comparison of stability constant data shows that the complexes $(\mathrm{M} \cdot \mathrm{X}-\mathrm{H} \cdot \mathrm{MP} \cdot \mathrm{H})^{ \pm}$and $(\mathrm{X}-\mathrm{H} \cdot \mathrm{MP} \cdot \mathrm{M})^{-}$dominate, meaning that in the first one $\mathrm{M}^{2+}$ is located at $\mathrm{N} 7$ and $\mathrm{H}^{+}$at the phosphate group, whereas in the second one the deprotonated phosphate group is the primary binding site. In both types of complexes macrochelates form: In the protonated case ca $65 \%$ occur, rather independent of $\mathrm{M}^{2+}\left(\mathrm{Mg}^{2+}\right.$, $\mathrm{Mn}^{2+}$ or $\mathrm{Zn}^{2+}$ ) indicating outersphere coordination, whereas varying extents of innersphere N7-macrochelates form in the phosphatecoordinated species (ca $0 \%$ with $\mathrm{Mg}^{2+}, 50 \%$ with $\mathrm{Mn}^{2+}$, and $90 \%$ with $\left.\mathrm{Zn}^{2+}\right)$.

Supported by the Department of Chemistry at the University of Basel.

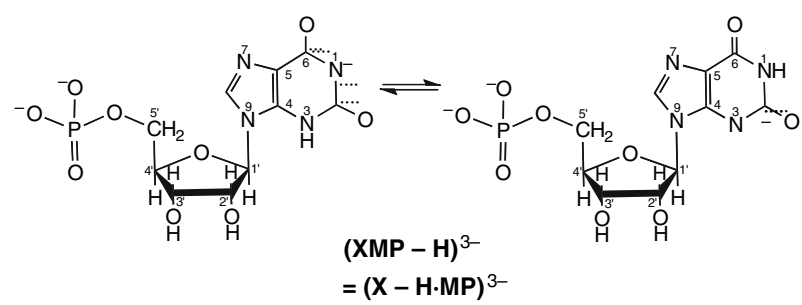


Reference

1. Sigel H, Operschall BP, Griesser R (2009) Chem Soc Rev 38 (in press)

\section{P457}

Kinetics and mechanism of the oxidation of purine derivatives coordinated to platinum(IV) complexes Sunhee Choi, Michelle Personick, Justin Bogart

Department of Chemistry and Biochemistry, Middlebury College, Middlebury, VT 05753, USA. choi@ middlebury.edu

Previous research in our lab showed that when $\mathrm{Pt}^{\mathrm{IV}}$ is bound to N7 of the $\mathrm{G}$ derivatives such as $5^{\prime}$-dGMP and $3^{\prime}$-dGMP, two electrons transfer from $\mathrm{G}$ to $\mathrm{Pt}^{\mathrm{IV}}$. The redox reaction is initiated by the intramolecular nucleophile (5'-phosphate and $5^{\prime}-\mathrm{OH}$, respectively) attacking $\mathrm{C} 8$ to form a cyclic intermediate of $\mathrm{G}$ and $\mathrm{Pt}^{\mathrm{II}}$. In this study we report that the redox reaction can also occur through intermolecular nucleophiles such as hydroxide and phosphate. The HPLC and LC/MS identified 8-oxo-G as the final products from both hydroxide and phosphate reactions. The reactions in $\mathrm{H}_{2}^{18} \mathrm{O}$ revealed that the oxygen atom in the hydroxide and phosphate ends up at the $\mathrm{C} 8$ position of 8 -oxo-G. The HPLC and ${ }^{31} \mathrm{P}-\mathrm{NMR}$ detected a phosphoester intermediate. The kinetics of the redox reaction was studied by monitoring the disappearance of $\mathrm{Pt}^{\mathrm{IV}}-\mathrm{G}$ by UV-vis spectroscopy. The reaction was first order with respect to both $\mathrm{Pt}^{\mathrm{IV}}-\mathrm{G}$ and $\mathrm{OH}^{-}$(and phosphate). The kinetic isotope effect of $\mathrm{H} 8$ was determined to be relatively small, which suggests the removal of $\mathrm{H} 8$ is reversible. These results led us to propose the redox mechanism in Scheme 1.

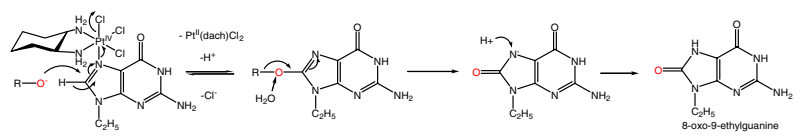

Scheme 1 Proposed mechanism of oxidation of 9-EtG by intermolecular nucleophile, where $\mathrm{R}=\mathrm{H}$ or $\mathrm{H}_{2} \mathrm{PO}_{3}$

\section{References}

1. Choi $S$ et al (2008) Inorg Chem 47:1352-1360

2. Choi S et al (2004) J Am Chem Soc 126:591-598

3. Choi S et al (2005) J Am Chem Soc 127:1773-1781

4 Choi $S$ et al (2006) Inorg Chem 45:10108-10114

\section{P458}

\section{Characterization of mercury-modified base pairs in a RNA duplex}

Susann Paulus ${ }^{1}$, Nicole Düpre ${ }^{2}$, Silke Johannsen ${ }^{1}$, Peter W. Thulstrup ${ }^{3}$, Lars Hemmingsen ${ }^{3}$, Jens Müller ${ }^{2}$, Roland K.O. Sigel ${ }^{1}$

${ }^{1}$ Institute of Inorganic Chemistry, University of Zürich, 8057 Zürich, Switzerland.

${ }^{2}$ Institute of Inorganic and Analytical Chemistrys, Westfälische Wilhelms-Universität Münster, 48149 Münster, Germany.

${ }^{3}$ Department of Basic Science and Environment, University of Copenhagen, 1871 Frederiksberg C, Denmark.

supaulus@aci.uzh.ch

Metal ion-mediated base pairs in nucleic acids are not only crucial in the light of RNA tertiary structure and mechanism but also for potential applications as molecular wires [1]. Using in vitro transcription we synthesized single-stranded RNA in high yield containing continuous stretches of uracil residues [2]. These RNAs rearrange upon the addition of $\mathrm{Hg}^{2+}$ from a hairpin containing mismatched U-U pairs to a more stable duplex by forming $\mathrm{Hg}^{2+}$-mediated
$\mathrm{U}-\mathrm{Hg}-\mathrm{U}$ base pairs. This structural conversion as well as the final RNA- $\mathrm{Hg}^{2+}$ scaffolds were characterized in detail by NMR, DLS, UV and $\mathrm{CD}$ spectroscopy [2]. In addition, to investigate the $\mathrm{Hg}^{2+}$-uracil coordination environment we used ${ }^{199 \mathrm{~m}} \mathrm{Hg}$ perturbed angular correlation of $\gamma$-rays (PAC) spectroscopy. This represents the first application of PAC spectroscopy to elucidate the local electronic and molecular structure of metalated nucleic acids. Finally, a comparison of the coordination geometry of corresponding metal ion-mediated base pairs in RNA and DNA is given.

Financial support by the European ERAnet-Chemistry, the Deutsche Forschungsgemeinschaft, the Swiss National Science Foundation, within the COST D39 Action, and the beam time grant IS448 from CERN/ISOLDE is gratefully acknowledged.

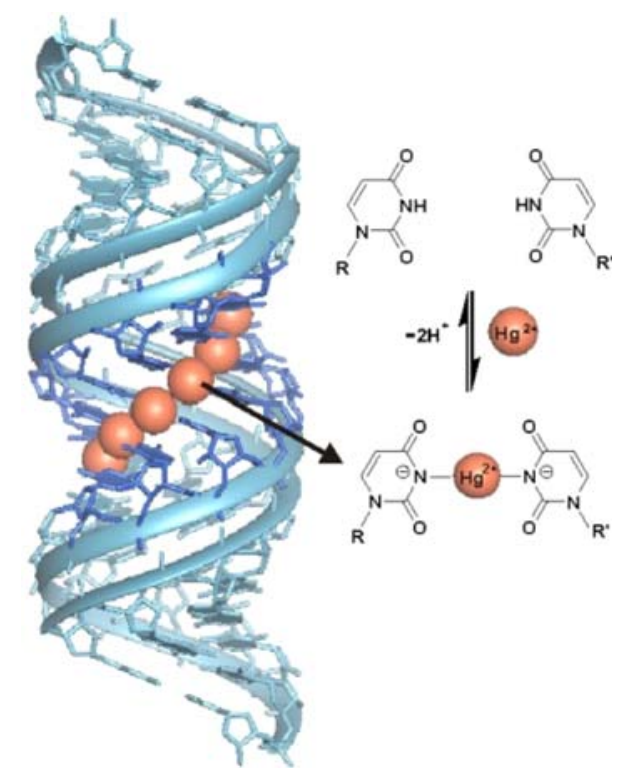

\section{References}

1. Müller J (2008) Eur J Inorg Chem 3749-3763

2. Johannsen S, Paulus S, Düpre N, Müller J, Sigel RKO (2008) J Inorg Biochem 102:1141-1151

\section{P459}

Synthesis, characterization, and reactivity of tetranuclear $\mathrm{Cu}(\mathrm{II})$ : complexes

with D-glucose 1-phosphate

Merii Kato $^{1,2}$, Tomoaki Tanase ${ }^{1}$

${ }^{1}$ Department of Chemistry, Faculty of Science, Nara Women's

University, Nara 630-8506, Japan.

${ }^{2}$ Toshiba Corporation Semiconductor Company, Mie 512-8550, Japan.tanase@cc.nara-wu.ac.jp, merii.kato@toshiba.co.jp We present tetranuclear $\mathrm{Cu}(\mathrm{II})$ complexes with a-D-glucose 1-phosphate (Glc-1P) with auxiliary nitrogen donor ligands (L) and their reactivity $[1,2]$. Reactions of $\mathrm{Na}_{2}[\mathrm{Glc}-1 \mathbf{P}]$ with $\mathrm{CuX}_{2} \cdot \mathrm{nH}_{2} \mathrm{O}$ in presence of bpy or phen (L) afforded tetranuclear complexes $\left[\mathrm{Cu}_{4}(\mu-\right.$ $\left.\mathrm{OH})(\mathrm{Glc}-1-\mathrm{P})_{2}(\mathrm{~L})_{4}\left(\mathrm{H}_{2} \mathrm{O}\right)_{2}\right] \mathrm{X}_{3}\left(\mathbf{1}: \mathrm{X}=\mathrm{NO}_{3}, \mathrm{~L}=\mathrm{bpy} ; \mathbf{2}: \mathrm{X}=\mathrm{Cl}\right.$, $\mathrm{L}=$ bpy; 3: $\mathrm{X}=\mathrm{Br}, \mathrm{L}=$ bpy; $4: \mathrm{X}=\mathrm{NO}_{3}, \mathrm{~L}=$ phen) (Fig. 1a, c). This is the first example of tetranuclear complex bridged by sugar phosphate esters. The $\left[\mathrm{Cu}_{4}(\mathrm{Glc}-1-\mathrm{P})_{2}(\mathrm{~L})_{4}\right]^{4+}$ units are very stable in solution and incorporate a series of sugar acids (SA) through the $\mathrm{Cu}_{4}$ core structural changes, affording the sugar-coated rectangular $\mathrm{Cu}_{4}$ 
clusters, $\left[\mathrm{Cu}_{4}\{(\mathrm{Glc}-1 \mathbf{P})\}_{2}(\mathrm{~m}-\mathrm{SA})_{2}(\mathrm{bpy})_{4}\right]^{2+}(\mathrm{SA}=$ D-gluconate $(\mathbf{6})$, D-glucuronate (7), and D-glucarateH (8b)), and linearly ordered chiral coordination polymers with D-glucarate $(\mathbf{8 b})$, lactobionate $(\mathbf{9})$. Reaction of 1 with $\mathrm{Na}_{2}\left[\mathrm{H}_{2} \mathrm{ATP}\right]$ gave the tetranuclear $\mathrm{Cu}$ (II) complex bridged by ATP, $\left[\mathrm{Cu}_{4}(\mathrm{ATP})_{2}(\mathrm{bpy})_{4}\right](\mathbf{5})$ (Fig. 1b, d).

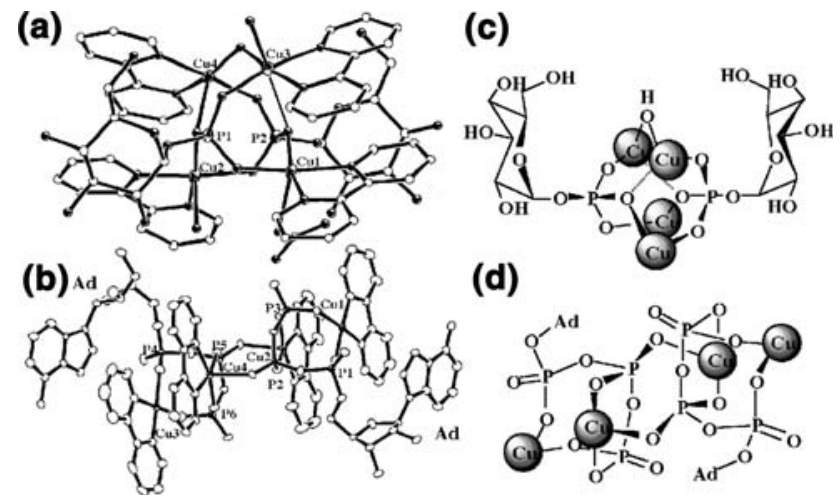

Fig. 1 Structures of $\mathbf{3}(\mathrm{a}, \mathrm{c})$ and $\mathbf{5}(\mathrm{b}, \mathrm{d})$

\section{References}

1. Kato M, Sah AK, Tanase T, Mikuriya M (2006) Inorg Chem 45:6646-6660

2. Kato M, Sah AK, Tanase T, Mikuriya M Eur J Inorg Chem 25042513 (2006)

\section{P460}

Design, structure-activity relationships and X-ray co-crystallography of anticancer-active polynuclear platinum(II) complexes.

Seiji Komeda ${ }^{1}$, Yuh-ling Lin ${ }^{2}$, Akira Odani ${ }^{3}$, Jan Reedijk ${ }^{4}$, Nicholas P. Farrell ${ }^{5}$, Loren D. Williams ${ }^{6}$, Masahiko Chikuma ${ }^{7}$

${ }^{1}$ Faculty of Pharmaceutical Science, Suzuka University Medical Science, Suzuka 513-8670, Japan.

${ }^{2}$ Department of Medicine, College of Medicine, Fu-Jen Catholic University, Taipei Hsien 24205, Taiwan.

${ }^{3}$ Faculty of Pharmaceutical Science, Kanazawa University, Kanazawa 920-1192, Japan.

${ }^{4}$ Leiden Institute of Chemistry, Leiden University, Leiden 2300RA, The Netherlands.

${ }^{5}$ Department of Chemistry, Virginia Commonwealth University, Richmond, VA 23284-2006, USA.

${ }^{6}$ School of Chemistry and Biochemistry, Georgia Institute of Technology, Atlanta, GA 30332-0400, USA.

${ }^{7}$ Graduate School of Pharmaceutical Science, Osaka University of Pharmaceutical Science, Takatsuki 569-1094, Japan.

komedas@suzuka-u.ac.jp

The series of polyamine- or azolato-bridged polynuclear Pt(II) complexes is a promising candidate for next-generation anticancer drugs [1], which could reduce potential side effects without spoiling therapeutic efficacy. Those polynuclear Pt(II) complexes are cationic species and interact with DNA, a probable target for Pt-based drugs, both covalently and non-covalently. The covalent and non-covalent Pt-DNA interaction modes were elucidated from X-ray crystal structures [2] and correlated with the anticancer activities of the Pt(II) complexes. A new series of polynuclear Pt(II) complexes has been synthesized based on the crystallographic study and exhibited higher cytotoxicity against a non-small cell lung cancer cells.

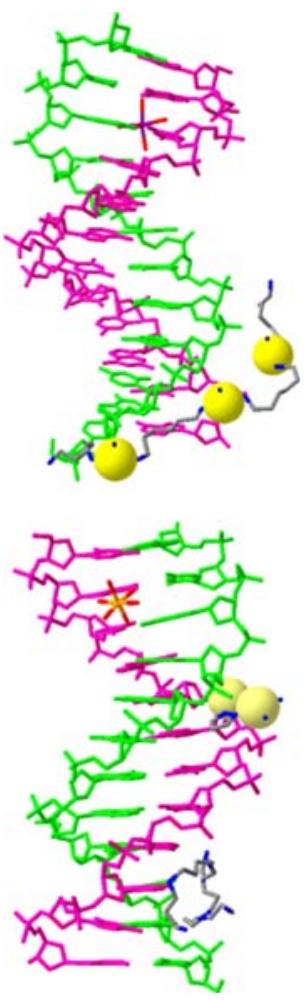

References

1. Komeda S, Lutz M, Spek AL, Yamanaka Y, Sato T, Chikuma M, Reedijk J (2002) J Am Chem Soc 124:4738-4746

2. Komeda S, Moulaei T, Woods KK, Chikuma M, Farrell NP, Williams LD (2006) J Am Chem Soc 128:16092-16103

\section{P461}

Stabilization of G-quadruplex DNA by metal complexes: a new approach for the development of anticancer drugs

Nurul Abd Karim ${ }^{1}$, Kogularamanan Suntharalingam ${ }^{1}$, Emma Child ${ }^{2}$, David Mann ${ }^{2}$, Ramon Vilar ${ }^{1}$

${ }^{1}$ Department of Chemistry, Imperial College London,

South Kensington, London SW7 2AZ, UK.

${ }^{2}$ Division of Cell and Molecular Biology, Imperial College London, South Kensington, London SW7 2AZ, UK. r.vilar@imperial.ac.uk

Guanine-rich DNA sequences can form quadruply-stranded structures in which guanine bases assemble into a planar structure via hydrogen bonds involving the Watson-Crick edge of one guanine and the Hoogsteen edge of its neighbor [1]. Recent bio-informatic studies have established that in the human genome there are ca. 350,000 guanine-rich sequences that can potentially form quadruplex DNA. Some of these sequences (e.g. telomeric DNA and DNA in promoter regions of some oncogenes such as c-myc) have been identified as targets for novel anticancer drugs. Our group was the first to show the advantages of using metal complexes to bind strongly to telomeric quadruplex DNA and in doing so inhibit telomerase [2-4]. In the current paper we will present our most recent results in this area. We have developed a series of novel poly-aromatic metal complexes (with $\mathrm{Cu}, \mathrm{Au}$ and $\mathrm{Pt}$ ) several of which bind strongly to quadruplex DNA. A particularly interesting feature of the complexes under study is their selectivity for c-myc quadruplex DNA over other DNA sequences. Since formation of quadruplex DNA in the promoter 
region c-myc has been postulated to regulate the expression of the oncogene, we have carried out biological studies to investigate this possibility. Indeed, these studies have shown that our complexes inhibit the expression of this oncogene.

\section{References}

1. Arola A, Vilar R (2008) Curr Top Med Chem 8:1405

2. Reed JE, Arola A, Neidle S, Vilar R (2006) J Am Chem Soc 128:5992

3. Arola A, Benet J, Neidle S, Vilar R (2008) Inorg Chem 47:11910

4. Reed JE, Neidle S, Vilar R (2007) Chem Comm 4366

\section{P462}

\section{Interaction of heterodinuclear cationic schiff base metal complex with DNA}

Sho Uehara, Midori Tojo, Yusuke Kitamura, Makoto Chikira

Department of Applied Chemistry, Chuo University,

Tokyo 112-8551, Japan. chikira@kc.chuo-u.ac.

Dinuclear metal complexes have been attracting much attention in developing efficient artificial metallonucleases due to the cooperative effect of the two metal centers on the binding and reaction with DNA. We have reported that dinuclear Ni(II) cationic Schiff-base complex (Fig. 1a) cleaved DNA with Oxone more mildly than salen-type mono nuclear $\mathrm{Ni}(\mathrm{II})$ complexes [1] while dinuclear $\mathrm{Cu}$ (II) complex (b) cleaved DNA with $\mathrm{H}_{2} \mathrm{O}_{2}$ more efficiently than the corresponding mono nuclear $\mathrm{Cu}$ (II) complexes [1, 2]. To understand such different behaviors of the complexes, we have synthesized $\mathrm{Cu}$ (II)-Ni(II) heterodinuclear complex (c) and investigated the interaction of the complex with DNA by using various spectroscopic methods and electrophoresis. By this complex, it became possible to use DNA-fiber EPR technique to analyze the orientation of the complex on DNA. The results indicated that (1) these complexes bind in the minor groove of double helical DNA at GC rich site and (2) (c) cleaves DNA with both Oxone and $\mathrm{H}_{2} \mathrm{O}_{2}$ but in milder fashion compared to (a) and (b), respectively. The effect of various scavengers will be presented to discuss the mechanism of the oxidative cleavage reactions.

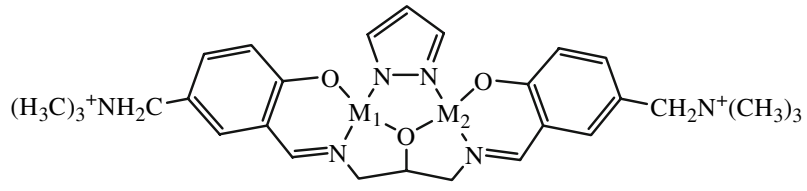

Fig. 1 Dinuclear complexes : (a) $\mathrm{M}_{1}=\mathrm{M}_{2}=\mathrm{Ni}(\mathrm{II})$, $\mathrm{M}_{1}=\mathrm{M}_{2}=\mathrm{Cu}(\mathrm{II}),\left(\right.$ c) $\mathrm{M}_{1}=\mathrm{Cu}(\mathrm{II}), \mathrm{M}_{2}=\mathrm{Ni}(\mathrm{II})$

\section{References}

1. Kakinuma Y, Arii H, Chikira M (2005) Abstract of ICBIC12

2. Tojo M, Tsuduku S, Tago A, Kakinuma Y, Kitamura Y, Tan T-H, Von S-T, Ng C-H, Chikira M (2008) Abstract of AsBIC4

\section{P463}

Thermodynamic studies for the DNA binding of iron(II)-phenanthroline and its derivatives: comparison between tris and mixed-ligand Complexes Mudasir $^{1}$, Endang Tri Wahyuni ${ }^{1}$, Naoki Yoshioka ${ }^{2}$, Hidenari Inoue ${ }^{2}$
${ }^{1}$ Department of Chemistry, Gadjah Mada University, Sekip Utara P.O. Box Bls. 21, Yogyakarta, Indonesia. ${ }^{2}$ Department of Applied Chemistry, Keio University, 3-14-1 Hiyoshi, Kohoku-ku, Yokohama 223-8522, Japan.m_mudasir@hotmail.com

Thermodynamic parameters including standard enthalpy $\left(\mathrm{D} H^{\circ}\right)$, entropy $\left(\mathrm{D} S^{\circ}\right)$ and free energy $\left(\mathrm{D} G^{\mathrm{o}}\right)$ changes for the DNA binding of tris and mixed-ligand iron(II) complexes of 1,10-phenanthroline (phen) and its derivatives, i.e. $\left[\mathrm{Fe}(\mathrm{phen})_{3}\right]^{2+},\left[\mathrm{Fe}(\mathrm{dmp})_{3}\right]^{2+}$, $\left[\mathrm{Fe}(\mathrm{tmp})_{3}\right]^{2+}[1],\left[\mathrm{Fe}(\mathrm{phen})_{2}(\mathrm{dip})\right]^{2+}[2]$ and $\left[\mathrm{Fe}(\mathrm{phen})_{2}(\mathrm{dppz})\right]^{2+}$ $[3,4](\mathrm{dmp}=4,7$-dimethyl-1,10-phen, $\operatorname{tmp}=3,4,7,8$ - tetramethyl1,10-phen; dip = 4,7-diphenyl-1,10-phen and dppz = dipyrido [3,2$\left.a: 2^{\prime}, 3^{\prime}-c\right]$ phenazine) has been studied by determining equilibrium binding constant $\left(K_{\mathrm{b}}\right)$ of the ct-DNA binding of iron(II) complexes at various temperatures. Results of study shows that the DNA binding of all investigated iron(II) complexes is endothermic and therefore entropically driven. Either planar aromatic or methyl substituents on phen ligand stabilize the DNA-binding event as indicated by the larger negative values of $\mathrm{DG}^{\mathrm{o}}$ for their DNA-binding. However, the stabilization effect of planar aromatic substituents is more pronounced. This is possibly due to more facilities available on aromatic substituents such hydrophobic and p-p stacking interactions.

\section{References}

1. Yoshioka MN, Inoue H (2008) Z Naturforsch 63b:37-46

2. Wijaya MK, Yoshioka N, Inoue H (2003) J Inorg Biochem 94:263-271

3. Wijaya MK, Tjahjono DH, Yoshioka N, Inoue H (2004) Z Naturforsch 59b:310-318

4. Wijaya MK, Wahyuni ET, Yoshioka N, Inoue H (2006) Biophys Chem 121:44-50

\section{P464}

Dual role of zinc finger in nuclear import of transcription factor $\mathrm{Sp1}$

Jun Kuwahara ${ }^{1}$, Haruka Kitamura ${ }^{1}$, Chisana Uwatoko ${ }^{1}$, Tatsuo Ito ${ }^{2}$, Kohji Itoh ${ }^{2}$

${ }^{1}$ Department of Molecular Biophysics and Chemistry,

Faculty of Pharmaceutical Science, Doshisha Women's University, Kyotanabe City, Kyoto 610-0395, Japan.

${ }^{2}$ Department of Medical Biotechnology, Institute of Medical

Research, Graduate School of Pharmaceutical Science,

The University of Tokushima, Tokushima 770-8505, Japan. jkuwahar@dwc.doshisha.ac.jp

Zinc finger proteins are among the most abundant proteins in eukaryotic genomes and extraordinarily diverse functions. In particular, the classical $\mathrm{C} 2 \mathrm{H} 2$ zinc fingers possess the characteristics of tandem repeats of zinc-binding module and vary in function, which ranges from DNA to RNA binding. We have been intrigued by versatility of this type of motif. Sp1 is a human ubiquitous transcription factor involved in the early development of an organism and comprises three tandem repeats of $\mathrm{C} 2 \mathrm{H} 2$ zinc finger motif and binds directly to a GC-rich element DNA (GC box), [1]. Bidirectional traffic across the nuclear envelope is routed through the nuclear pore complex (NPC). Nuclear import of globular proteins of greater than $60 \mathrm{kDa}$ in size is an active process that requires the presence of a suitable nuclear localization signal (NLS) and is mediated by a related family of shuttling transport factors, importins, which can recognize NLS. Like other nuclear proteins, Sp1 is supposed to be actively transported into the nucleus due to its molecular mass $(95 / 105 \mathrm{kDa})$, 
none of NLS for Sp1 has been reported. We found that $\mathrm{C} 2 \mathrm{H} 2$ zinc fingers of Sp1 serve as NLS and can recognize importins [2].

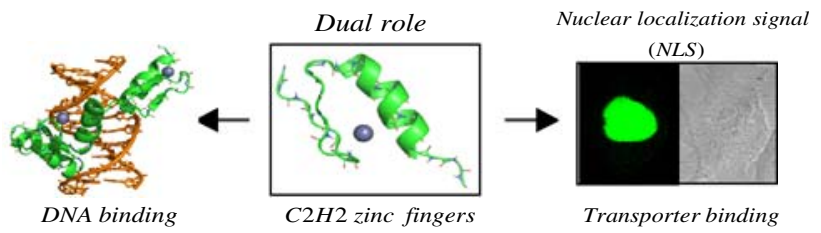

\section{References}

1. Kuwahara J, Coleman JE (1990) Biochemistry 29:8627-8631

2. Ito T, Azumano M, Uwatoko M, Itoh CK, Kuwahara J Biochem Biophys Res Commun 380:28-32 (2009)

\section{P465}

\section{Mechanisms for copper/catechol-induced DNA damage} and its universal suppression system

Motozumi Ando, Rena Makino, Tsuyoshi Nakai, Yoshihiko Nishino, Koji Ueda, Chitose Toda, Yoshinori Okamoto, Hiroyuki Nishida, Nakao Kojima

Faculty of Pharmacy, Meijo University, Nagoya 468-8503, Japan. o0874501@ccmailg.meijo-u.ac.jp

Oxidative stress is involved in various diseases such as cancer and neurodegenerative disorders. Catechol plus $\mathrm{Cu}(\mathrm{II})$ are known to induce oxidative DNA damage via redox reaction. We found that the oxidative DNA damage as well as the conformational change were suppressed by attaching the $\alpha$-carbonyl side chain on catechol ring (catechol derivatives). In this study, we investigated a redox reaction manner between $\mathrm{Cu}(\mathrm{II})$ and the catechol derivatives using $\mathrm{UV}, \mathrm{CD}$ and ${ }^{1} \mathrm{H}-\mathrm{NMR}$ and solid phase extraction. Although catechol was oxidized to $o$-quinone by $\mathrm{Cu}$ (II) based on the UV spectral analysis, the oxidation of the catechol derivatives was incomplete, suggesting an oxidation to semiquinone. ${ }^{1} \mathrm{H}-\mathrm{NMR}$ analysis indicated no further oxidation of the derivatives to $o$-quinone. Also, the oxidized product was eluted together with $\mathrm{Cu}(\mathrm{I})$ in solid phase extraction. This strongly indicates the formation of a complex between the derivatives and $\mathrm{Cu}(\mathrm{I})$, which is essential for DNA oxidation and conformational change. In conclusion, the carbonyl side chain suppressed the catechol-induced DNA damages through both sequestering copper by their semiquinones and stopping the catechol redox cycling. This suppression system is universally used in the living system including natural products.

\section{P466}

Ruthenium (III) complexes with bidentate Schiff bases. Preliminary interaction of Tetraethylamonium dichloro-bis[N-phenyl-4-bromo-salicylideniminato$\mathrm{N}, \mathrm{O}]$ ruthenat(III) with DNA

Emira Kahrovic $^{1}$, Shefket Dehari, Dije Dehari ${ }^{2}$, Selim Jusufi, Hysen Reçi ${ }^{3}$, Sabina Begic and Nevzeta Ljubijankic ${ }^{1}$
${ }^{1}$ Department of Chemistry, University of Sarajevo, Faculty of Science, Bosnia and Herzegovina.

${ }^{2}$ Department of Chemistry, Faculty of Mathematical and Natural Sciences, State University of Tetovo, Republic of Macedonia. ${ }^{\mathbf{3}}$ Department of Chemistry, Faculty of Mathematical and Natural Sciences, University of Prishtina, Republic of Kosovo.

emira_kahrovic@yahoo.com

With respect to the promising antitumor properties of some ruthenium(III) compounds we started synthesis and preliminary study in solution (hydrolysis and reactivity toward DNA) of ruthenium(III) with Schiff bases. Two complexes derived from 4-X-salicylaldehyde $(\mathrm{X}=\mathrm{Cl}, \mathrm{Br})$ and aniline are formulated $\left[\mathrm{Ru}(\mathrm{SB})_{2} \mathrm{Cl}_{2}\right] \mathrm{Et}_{4} \mathrm{~N}$. On the ground of elemental analyzes, Ir, electronic, ${ }^{1} \mathrm{H}-\mathrm{NMR}$ spectral data and mass spectrometry the following octahedral structure has been tentatively proposed for titled compound.<smiles>CCN(CC)CCOP(Cl)(Cl)(N=Cc1cc(Br)ccc1OC)N(c1ccccc1)c1ccccc1</smiles>

We assume that only slight increasing of absorbance of DNA (calf thymus) in the presence of titled compound at $260 \mathrm{~nm}$ over five hours could be superimposed by the hydrolytic effect of ruthenium complex.

\section{P467}

\section{New ferrocene-PNA conjugates as electrochemical DNA} biosensors

Nina Hüsken, Nils Metzler-Nolte

Faculty for Chemistry and Biochemistry, Ruhr-Universität Bochum, 44801 Bochum, Germany. Nils.Metzler-Nolte@rub.de

Peptide nucleic acids (PNA's) are an excellent tool for the specific detection of DNA and RNA. Exceptional hybridization properties allow a selective and specific binding to nucleic acid target sequences and a reliable discrimination of single-nucleotide point mutations. The labeling of PNA with electrochemically active metal complexes enables an application as recognition device of an electrochemical DNA biosensor. We examined the click chemistry methodology as a new strategy for the $\mathrm{N}$-terminal labeling of PNA oligomers with ferrocene $(\mathrm{Fc})$ derivatives [1]. Electrochemical investigations of the new label patterns revealed a set of four Fc-PNA conjugates with distinguishable electrochemical formal potentials, comparable to a "four-color" detection system for the detection of SNP (singlenucleotide polymorphism) [2].

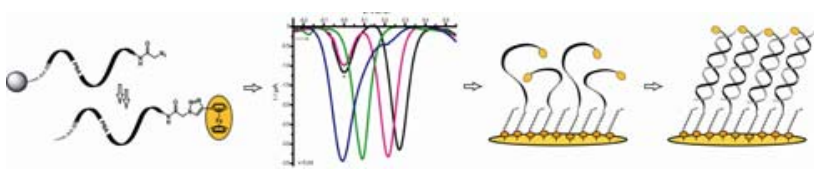

Self-assembled monolayers (SAM's) of thiol-modified Fc-PNA conjugates on polycrystalline gold surfaces were investigated with ToFSIMS, IR and XPS. The use of Fc-PNA SAM's on gold microelectrodes 
and microchips as electrochemical DNA biosensors was examined in hybridization experiments with fully-complementary and mismatch DNA analytes. Electroanalytical studies were performed applying cyclic voltammetry (CV), square wave voltammetry (SWV) and electrochemical impedance spectroscopy (EIS).

\section{References}

1. Gasser G, Hüsken N, Köster SD, Metzler-Nolte N (2008) Chem Commun 3675-3677

2. Hüsken N, Gasser G, Köster SD, Metzler-Nolte N (2009) (in press)

\section{P468}

Interactions of organometallic ruthenium arene anticancer complexes with DNA

Hong-Ke Liu', Fuyi Wang', Susan J. Berners-Price ${ }^{3}$, Peter J. Sadler 4

${ }^{1}$ Jiangsu Key Laboratory of Biofunctional Materials, School of Chemistry, Nanjing Normal University, China.

${ }^{2}$ Department of Chemistry, University of Warwick, Coventry UK.

${ }^{3}$ Department of Chemistry, The University of Western Australia, Australia. liuhongke@njnu.edu.cn

We have studied reactions of ruthenium arene anticancer complexes $\mathbf{1}$, $\mathbf{2}$ and $\mathbf{3}$ with the DNA I, II, and $\mathbf{V}$ by HPLC, ESI-MS, 1D, 2D ${ }^{1} \mathrm{H}$ and

${ }^{15} \mathrm{~N}$ NMR spectroscopy. These studies [2, 4] show that arene ligand plays a major role in distorting the duplex either via steric interactions or via intercalation, and significant differences are observed between $\mathbf{2}$ and 3. Studies of the time dependence [5] of reactions of ${ }^{15} \mathrm{~N}-\mathbf{1}$ or ${ }^{15} \mathrm{~N}-\mathbf{2}$ with $\mathbf{V}$, show that the arene ligand plays a major role in controlling the kinetic and thermodynamic processes. These results provide a structural basis for understanding their biological effects.

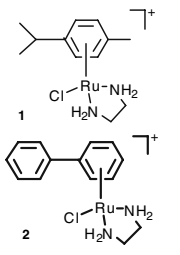

$$
\begin{aligned}
& \begin{array}{llllllllll}
\mathrm{C}_{1} & \mathrm{G}_{2} & \mathrm{G}_{3} & \mathrm{C}_{4} & \mathrm{C}_{5} & \mathrm{G}_{6}
\end{array} \\
& \begin{array}{lllllll}
\mathrm{C}_{1} & \mathrm{G}_{2} & \mathrm{G}_{3} & \mathrm{C}_{4} & \mathrm{C}_{5} & \mathrm{G}_{6}
\end{array} \\
& \begin{array}{lllllll}
\mathrm{G}_{1}{ }_{2} \mathrm{C}_{1}{ }_{1} \mathrm{C}_{1} & 0 & \mathrm{G}_{9} & \mathrm{G}_{8} & \mathrm{C}_{7}
\end{array} \\
& \text { A T A } C_{4} \quad \text { A T G G } G_{8} \quad \text { T A } C_{1} 1 \text { A T A III } \\
& \mathrm{TA} \mathrm{A} \mathrm{G}_{2}{ }_{5} \mathrm{TAC}_{2} \mathrm{C}_{2}{ }_{1} \mathrm{~A} \mathrm{~T} \mathrm{G}_{18} \mathrm{TA} \text { A IV } \\
& \text { III }+ \text { IV }=\operatorname{duplex} \mathrm{V}
\end{aligned}
$$

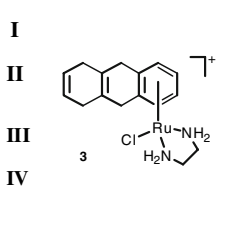

We thank the Wellcome Trust, BBSRC, ORS, Oncosense Ltd, NSF 20871069 and JSSF BK2008428 for their support for this work.

\section{References}

1. Morris RE, Aird RE, Jodrell DI, Sadler PJ (2001) J Med Chem 44:3616

2. Liu HK, Wang F, Parkinson J, Bella J, Sadler PJ (2006) Chem Eur J 12:6151

3. Liu HK, Berners-Price S, Wang F, Sadler PJ (2006) Angew Chem Int Ed 45:8153

4. Liu HK, Parkinson J, Bella J, Wang F, Sadler PJ (2009) (in press)

5. Liu HK, Berners-Price S, Wang F, Sadler PJ (2009) (in press)

\section{P469}

On the reactivity of ammonia ligands of cisplatin: dual affinity of a cis- $\left(\mathrm{NH}_{3}\right)_{2} \mathrm{Pt}^{\mathrm{II}}$ nucleobase complex for both anions and cations

Pablo J. Sanz Miguel, Lu Yin, Wei-Zheng Shen, Bernhard Lippert
Department of Bioinorganic Chemistry, TU Dortmund University, 44227 Dortmund, Germany. pablo.sanz@tu-dortmund.de, bernhard.lippert@tu-dortmund.de

Cationic metal complexes, in the solid state, interact in one way or another with (1) the counter anion(s). However, it is less frequent that (2) such interactions, e.g. through hydrogen bonding, also persist in solution. And it is even more seldom that (3) cationic complexes bind additional metal ions to form larger aggregates. With the here reported dinuclear head-tail model nucleobase complex $\{$ cis$\left.\left[\mathrm{Pt}\left(\mathrm{NH}_{3}\right)_{2}\left(1-\mathrm{MeC}^{-}-\mathrm{N} 3, N 4\right)\right]_{2}\right\}^{2+}\left(\{\mathbf{M C}\}\right.$, with $1-\mathrm{MeC}^{-}=1-$ methylcytosinate) all three options (1)-(3) are realized.

This work adds to the reactivity of $\mathrm{NH}_{3}$ ligands of cisplatin [1]. The four ammonia ligands provide a "rack" for anion binding through hydrogen bond formation, as demonstrated for the nitrate (1), mixed nitrate, chloride (2), and bromide (3) salts. $\mathrm{Cl}^{-}$binding is also evident from ${ }^{1} \mathrm{H}$ NMR spectra in solution. Treatment of 1 with $\mathrm{AgNO}_{3}$ yields $\{\mathbf{M C}\} \operatorname{Ag}\left(\mathrm{NO}_{3}\right)_{3} \cdot$ aq (4), a helical coordination polymer with an infinite $\left(\mathrm{Pt}_{2} \mathrm{Ag}\right)_{n}$ chain and with $\mathrm{Ag}^{+}$ions binding to the available $\mathrm{O} 2$ sites of the $1-\mathrm{MeC}^{-}$ligands. Both left- and right- handed helices are present in the crystal [2].

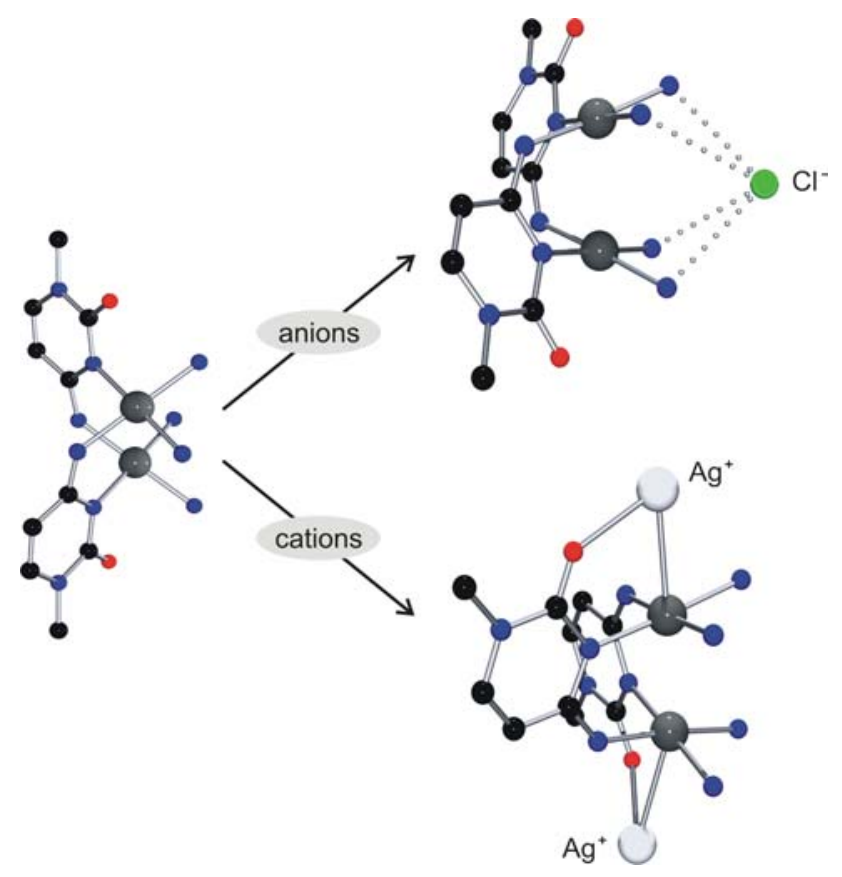

References

1. Kampf G, Sanz Miguel PJ, Morell Cerdà M, Willermann M, Schneider A, Lippert B (2008) Chem Eur J 14:6882-6891

2. Yin L, Shen W-Z, Sanz Miguel PJ, Lippert B (submitted)

P470

DNA binding and prominent DNA cleavage and anticancer activities of certain iron(II) complexes of diimine ligands

S. Ramakrishnan, ${ }^{1}$ E. Suresh, ${ }^{2}$ A. Riyasdeen, ${ }^{3}$ M. A. Akbarsha ${ }^{3}$ and M. Palaniandavar ${ }^{{ }^{*}}$ 
${ }^{1}$ Centre for Metals in Medicine and Biology, School of Chemistry, Bharathidasan University, Tiruchirappalli 620 024, India. ${ }^{2}$ Analytical Science Discipline, Central Salt and Marine Chemicals Research Institute, Bhavnagar-364 002, India. ${ }^{3}$ Department of Animal Science, Bharathidasan University, Tiruchirappalli 620 024, India.

palanim51@yahoo.com

There is considerable attention focused on the design of new metalbased drugs that exhibit enhanced selectivity and novel modes of DNA interaction like non-covalent interactions that mimic the mode of interaction of proteins with DNA. Recently, we have reported from our laboratory the non-covalently DNA binding and cleaving mixed ligand biocompatible copper(II) [1] and ruthenium(II) [2] complexes. Such complexes have received considerable attention during the past few years in an attempt to replace the widely used anticancer drug cisplatin. Also, certain mixed ligand copper(II) complexes exhibit cytotoxicities, which approximately equal to cisplatin for 24 and $48 \mathrm{~h}$ incubation respectively and the complexes mediate apoptosis, necrosis and mitotic catastrophe in the cell cycle progression at 24 and $48 \mathrm{~h}$ harvesting time [3]. Further, One of the most strongly DNA binding fluxional copper(II) complex, which exhibits prominent DNA cleavage in the presence of $\mathrm{H}_{2} \mathrm{O}_{2}$ [4]. In this work we have isolated and studied certain mononuclear iron(II) complexes like [Fe(diimine $\left.)_{3}\right]^{2+}$, where diimine $=$ bpy $(\mathbf{1})$, phen $(\mathbf{2}), 5,6-\mathrm{dmp}(\mathbf{3})$ and dpq (4). The structure of one of the complexes has been characterized by $\mathrm{X}$-ray crystallography. The DNA binding and cleavage and anticancer activities of the complexes have been carried out using different physical and biochemical methods. The results of our systematic investigation will be presented and discussed.
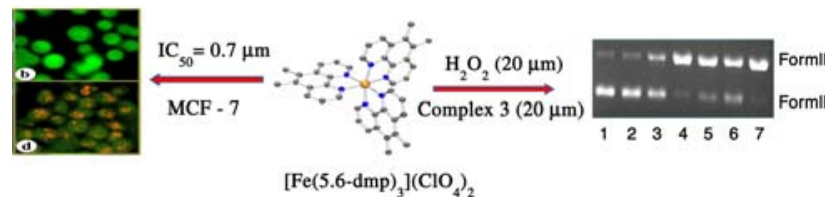

$\left[\mathrm{Fe}(5.6-\mathrm{dmp})_{3}\right]\left(\mathrm{ClO}_{4}\right)_{2}$

References

1. Rajendiran V, Karthik M, Periyasamy VS, Akbarsha MA, Srinag BS, Krishnamurthy H, Palaniandavar M (2007) Inorg Chem 46:8208 2. Rajendiran V, Murali M, Suresh E, Sinha S, Somasundaram K, Palaniandavar M (2008) Dalton Trans 148

3. Ramakrishnan S, Rajendiran V, Periyasamy VS, Akbarsha MA, Srinag BS, Krishnamurthy H, Palaniandavar M (2009) Inorg Chem 48:1309

4. Ramakrishnan S, Palaniandavar M (2008) Dalton Trans 3866

\section{P471}

\section{Synthesis, characterization and DNA-interaction} of two mononuclear $\mathrm{Ru}(\mathrm{III})$ complexes with ofloxacin and levofloxacin

Valentina Uivarosi ${ }^{1}$, Mihaela Badea ${ }^{2}$, Rodica Olar ${ }^{2}$,

Daniela Iacob $^{1}$, Victoria Aldea ${ }^{1}$, Dana Marinescu ${ }^{2}$, Bruno Stefan Velescu $^{3}$

${ }^{1}$ Department of Inorganic Chemistry, Faculty of Pharmacy, Carol Davila University of Medicine and Pharmacy, Bucharest 020956, Romania.

${ }^{2}$ Department of Inorganic Chemistry, Faculty of Chemistry, University of Bucharest, Bucharest 050663, Romania.

${ }^{3}$ Department of Pharmacology and Clinical Pharmacy, Faculty of Pharmacy, Carol Davila University of Medicine and Pharmacy, Bucharest 020956, Romania. valentina_uivarosi@yahoo.com Two mononuclear complexes of the second-generation quinolone antibacterial agent ofloxacin and third generation agent levofloxacin with $\mathrm{Ru}(\mathrm{III})$ have been prepared and characterized by elemental analysis, conductivity measurements, thermal analysis (TG, DTG,
DTA) and some spectral properties (UV-Vis, IR, fluorescence). The resultant complexes were formulated as $\mathrm{RuL}_{2}(\mathrm{DMSO})_{m} \mathrm{Cl}_{3} \cdot n \mathrm{H}_{2} \mathrm{O}((\mathbf{1})$ L:ofloxacin, $m=1, n=1$; (2) L:levofloxacin, $m=2, n=8$; DMSO: dimethylsulfoxide) and their most probable structures have been proposed. The biological activity of the complexes has been evaluated by DNA-binding capacity with UV and fluorescence spectroscopies.

\section{P472}

\section{Targeting telomeric DNA with platinum-perylene conjugates}

Lu Rao, Joshua D. Dworkin, William E. Nell, Ulrich Bierbach Department of Chemistry, Wake Forest University, Winston-Salem, North Carolina 27109, USA. raol4@wfu.edu

Human telomeres consist of tandem repeats of the sequence TTAGGG.. In most cancer cells, the single-stranded $3^{\prime}$ overhang of telomeric DNA is maintained at a relatively short but stable length by the up-regulated enzyme telomerase. Inhibition of telomere elongation by telomerase by making the single-strand inaccessible to the enzyme may interfere with the proliferation of cancer cells. The single-stranded overhang has the potential to form a non-classical secondary structure known as G-quadruplex, in which four guanine (G4) bases are linked by Hoogsteen hydrogen bonding. We have developed a platinum-based drug, PT-ACRAMTU, that binds with high affinity to nitrogen of adenine (A). Because the G-N7 sites (the primary target in dsDNA) in quadruplex DNA are involved in hydrogen bonding, PT-ACRAMTU shows enhanced binding with the loop adenines. Inspired by this altered binding preference, a novel perylene analogue of PT-ACRAMTU was designed as a quadruplexspecific agent. CD spectroscopy and electrospray mass spectrometry were used to investigate the G4 binding properties of the compound. The platinum-perylene binds to G-quadruplexes with a stoichiometry of $2: 1$ and shifts the equilibrium between two G-quadruplex structures from the parallel to the anti-parallel form. Molecular mechanics/ molecular dynamics calculations were used to explore the structural and energetic basis of the conformational switch and to assist the design of effective G-quadruplex-specific cross-linking agents.

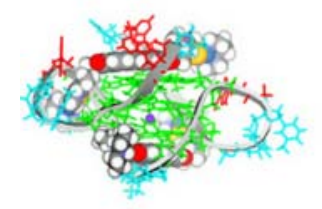

Parallel

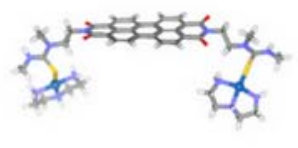

Platinum-Perylene Conjugate

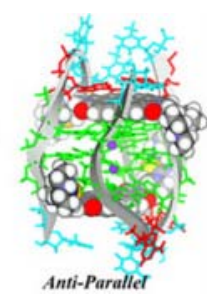

Anti-Parallet
P473

Development of a novel sensor to determine the concentration of heavy metal cations: application of the novel specific interaction between heavy metal cation and mismatch DNA base pair

Tetsuo Kozasa ${ }^{1}$, Yukako Miyakawa', Yoshiyuki Tanaka ${ }^{2}$, Akira $\mathrm{Ono}^{3}$, and Hidetaka Torigoe ${ }^{1}$

${ }^{1}$ Department of Applied Chemistry, Faculty of Science,

Tokyo University of Science, Tokyo 162-8601, Japan.

${ }^{2}$ Graduate School of Pharmaceutical Science, Tohoku University,

Sendai 980-8578, Japan.

${ }^{3}$ Department of Applied Chemistry, Faculty of Engineering,

Kanagawa University, Yokohama 221-8686, Japan.

htorigoe@ rs.kagu.tus.ac.jp

Recently, we found the specific interaction between $\mathrm{Hg}(\mathrm{II})$ cation and $\mathrm{T}: \mathrm{T}$ mismatch base pair, and that between $\mathrm{Ag}(\mathrm{I})$ cation and $\mathrm{C}: \mathrm{C}$ mismatch base pair in duplex DNA [1-3]. In this study, using the 
novel specific interactions, we have developed a novel sensor to determine the concentration of each of $\mathrm{Hg}$ (II) and $\mathrm{Ag}$ (I) cation. The sensor is composed of a T-rich or C-rich oligonucleotide, attached with the fluorophore, 6-carboxyfluorescein (6-Fam), and the quencher, dabcyl, to the $5^{\prime}$ and $3^{\prime}$ termini, respectively. The presence of $\mathrm{Hg}(\mathrm{II})$ or $\mathrm{Ag}(\mathrm{I})$ cation may induce the formation of the hairpin structure by the $\mathrm{T}-\mathrm{Hg}-\mathrm{T}$ or $\mathrm{C}-\mathrm{Ag}-\mathrm{C}$ novel specific interaction. Because the hairpin structure should bring the fluorophore and the quencher into close enough proximity for energy transfer, fluorescence resonance energy transfer (FRET)-mediated quenching between the fluorophore and the quencher may be observed. In fact, the intensity of 6-Fam emission at $520 \mathrm{~nm}$ was decreased almost linearly, when the concentration of $\mathrm{Hg}$ (II) or $\mathrm{Ag}(\mathrm{I})$ cation was increased. We conclude that, using the novel sensor in this study, the concentration of $\mathrm{Hg}(\mathrm{II})$ or $\mathrm{Ag}(\mathrm{I})$ cation can be determined from the intensity of 6-Fam emission at $520 \mathrm{~nm}$.

\section{References}

1. Ono A, Togashi H (2004) Angew Chem Int Ed 43:4300-4302

2. Torigoe H, Kawahashi K, Takamori A, Ono A (2005) Nucleosides Nucleotides Nucleic Acids 24:915-917

3. Ono A, Cao S, Togashi H, Tashiro M, Fujimoto T, Machinami T, Oda

S, Miyake Y, Okamoto I, Tanaka Y Chem Commun 4825-4827 (2008)

\section{P474}

Development of a novel device to trap heavy metal cations: application of the novel specific interaction between heavy metal cation and mismatch DNA base pair

Tetsuo Kozasa ${ }^{1}$, Yukako Miyakawa ${ }^{1}$, Yoshiyuki Tanaka ${ }^{2}$, Akira $\mathrm{Ono}^{3}$, and Hidetaka Torigoe ${ }^{1}$

${ }^{1}$ Department of Applied Chemistry, Faculty of Science, Tokyo University of Science, Tokyo 162-8601, Japan.

${ }^{2}$ Graduate School of Pharmaceutical Science, Tohoku University, Sendai 980-8578, Japan.

${ }^{3}$ Department of Applied Chemistry, Faculty of Engineering,

Kanagawa University, Yokohama 221-8686, Japan.

htorigoe@rs.kagu.tus.ac.jp

Recently, we found the specific interaction between $\mathrm{Hg}(\mathrm{II})$ cation and T:T mismatch base pair, and that between $\mathrm{Ag}(\mathrm{I})$ cation and C:C mismatch base pair in duplex DNA [1-3]. In this study, using the novel specific interactions, we have developed a novel device to trap each of $\mathrm{Hg}(\mathrm{II})$ and $\mathrm{Ag}(\mathrm{I})$ cation. The device is composed of a $5^{\prime}$-biotinylated T-rich or C-rich oligonucleotide immobilized on a streptavidin-coated polystyrene bead. When the beads are added to a solution containing $\mathrm{Hg}(\mathrm{II})$ or $\mathrm{Ag}(\mathrm{I})$ cation, $\mathrm{Hg}$ (II) or $\mathrm{Ag}(\mathrm{I})$ cation can be trapped by the immobilized T-rich or C-rich oligonucleotide through the T-Hg-T or CAg-C novel specific interaction. After the beads trapping $\mathrm{Hg}$ (II) or $\mathrm{Ag}(\mathrm{I})$ cation are collected by centrifugation, $\mathrm{Hg}(\mathrm{II})$ or $\mathrm{Ag}(\mathrm{I})$ cation can be removed from the solution. The efficiency of the beads to trap $\mathrm{Hg}$ (II) or $\mathrm{Ag}(\mathrm{I})$ cation can be estimated by measuring the concentration of the remaining $\mathrm{Hg}$ (II) or $\mathrm{Ag}(\mathrm{I})$ cation after the removal of the $\mathrm{Hg}(\mathrm{II})$ - or $\mathrm{Ag}(\mathrm{I})$-trapping beads. In fact, almost all of $\mathrm{Hg}(\mathrm{II})$ or $\mathrm{Ag}(\mathrm{I})$ cation was removed by the treatment of an enough amount of the beads. We conclude that, using the novel device in this study, $\mathrm{Hg}$ (II) or $\mathrm{Ag}(\mathrm{I})$ cation can be effectively removed from the solution.

\section{References}

1. Ono A, Togashi H (2004) Angew Chem Int Ed 43:4300-4302

2. Torigoe H, Kawahashi K, Takamori A, Ono A (2005) Nucleosides Nucleotides Nucleic Acids 24:915-917

3. Ono A, Cao S, Togashi H, Tashiro M, Fujimoto T, Machinami T, Oda

S, Miyake Y, Okamoto I, Tanaka Y Chem Commun 4825-4827 (2008)

\section{P475}

Studies on the mechanism of action of an efficient vanadium inorganic nuclease, $\mathrm{V}^{\mathrm{IV}} \mathrm{O}$ (acac) Isabel Cavaco ${ }^{1,2}$, Nataliya Butenko ${ }^{1}$, Ana Isabel Tomaz ${ }^{3}$, Vera Ribeiro ${ }^{4}$, João Costa Pessoa ${ }^{2}$

${ }^{1}$ Dep. de Química, Bioquímica e Farmácia, Universidade do Algarve, Campus de Gambelas, 8005-139 Faro, Portugal.

${ }^{2}$ Centro de Química Estrutural, Instituto Superior Técnico, TU

Lisbon, Av Rovisco Pais, 1049-001 Lisboa, Portugal.

${ }^{3}$ Centro de Ciências Moleculares e Materiais, Fac. de Ciências da

Universidade de Lisboa, Campo Grande, Lisboa, Portugal.

${ }^{4}$ Centro de Biomedicina Molecular e Estrutural, Universidade do Algarve, Campus de Gambelas, 8005-139 Faro, Portugal.

icavaco@ualg.pt

Among the several transition metal compounds that have shown nuclease activity some examples are of vanadium complexes. Among these we found $\mathrm{V}^{\mathrm{IV}} \mathrm{O}(\mathrm{acac})_{2}$ to be one of the most active. It requires no activating agents, no air and no irradiation to degrade DNA (2). The presence of $\mathrm{H}_{2} \mathrm{O}_{2}, \mathrm{O}_{2}$ or oxone enhances its cleavage activity, and the formation of ROS was detected from the fluorescence of terephthalic acid solutions. Circular dichroism measurements show low intensity signals in the 300-400 nm range, indicating an interaction between the metal complex and DNA. This evidence points to more than one possible pathway: (a) oxidation in the presence of $\mathrm{O}_{2}$, involving ROSprobably $\mathrm{OH}$ radicals; (b) hydrolytic degradation by direct interaction of $\mathrm{V}^{\mathrm{IV}} \mathrm{O}(\mathrm{acac})_{2}$ with DNA, possibly at the phosphodiester bonds.

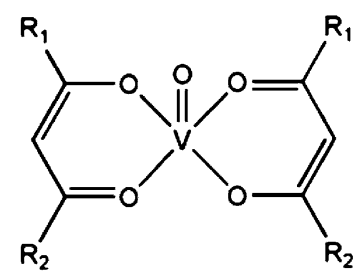

$$
\begin{aligned}
& \text { 1: } R_{1}=R_{2}=C_{3} \\
& \text { 2: } R_{1}=R_{2}=C_{2} H_{5} \\
& \text { 3: } R_{1}=C_{3} ; R_{2}=N_{2} \\
& \text { 4: } R_{1}=\mathrm{CH}_{3} ; R_{2}=N\left(C_{3}\right)_{2}
\end{aligned}
$$

\section{Reference}

1. Butenko N, Tomaz AI, Nouri O, Escribano E, Moreno V, Gama S, Ribeiro V, Telo JP, Costa Pesssoa J, Cavaco I (2009) J Inorg Biochem. doi:10.1016/j.jinorgbio.2009.01.003

\section{P476}

\section{Stereospecific repair of the $5 R$ spore photoproduct} by spore photoproduct lyase

Sunshine C. Silver, Tilak Chandra, Egidijus Zilinskas, Eric M. Shepard, William E. Broderick, Joan B. Broderick Department of Chemistry and Biochemistry, Montana State University, Bozeman, MT 59717. jbroderick@ chemistry.montana.edu Spore forming organisms are a health to humans and other animals in part due to a remarkable resistance to UV irradiation. This resistance results from two events: first, the formation of a unique thymine dimer, 5-thyminyl-5,6-dihydrothymine (spore photoproduct, or SP) upon UV irradiation; and more importantly, the rapid and specific repair of this DNA lesion to two thymines by the enzyme spore photoproduct lyase (SPL). SPL is a member of the radical SAM superfamily of enzymes and contains a $[4 \mathrm{Fe}-4 \mathrm{~S}]$ cluster. Understanding the molecular basis of this radical-mediated DNA repair will ultimately allow for a better understanding of how to address the health risks caused by spore forming bacteria. Upon UV irradiation of bacterial spores, two distinct diastereomers of SP ( $5 R$ or $5 S$ ) could in theory be formed. However, only the $5 R$ configuration is possible for SP formed from adjacent thymines in double helical DNA due to the 
constraints imposed by the DNA structure. Here we present evidence that SPL repairs only the $5 R$ isomer of SP, supporting the longstanding theory that SP is formed by dimerization of adjacent thymines in double-helical DNA.

\section{P477}

Characterization of the length and viscosity dependence of the end-to-end collision dynamics of single-stranded DNA

Takanori Uzawa ${ }^{1,2}$, Ryan R. Cheng ${ }^{3}$, Kevin J. Cash ${ }^{4}$,

Dmitrii E. Makarov ${ }^{3}$ and Kevin W. Plaxco ${ }^{1,5}$

${ }^{1}$ Department of Chemistry and Biochemistry,

${ }^{2}$ Department of Chemistry, Graduate School of Science,

Hokkaido University, Sapporo 060-0810, Japan,

${ }^{3}$ Department of Chemistry and Biochemistry, The University of

Texas at Austin, Austin, TX 78712, USA,

${ }^{4}$ Department of Chemical Engineering,

${ }^{5}$ Interdepartmental program in Biomolecular Science and

Engineering, UCSB, Santa Barbara, CA 93106 USA.

uzawa@sci.hokudai.ac.jp

Intramolecular dynamics play an essential role in the folding and function of biomolecules and, increasingly, in the operation of many biomimetic technologies. Thus motivated we have employed both experiment and simulation to characterize the end-to-end collision dynamics of unstructured, single-stranded DNAs ranging from 6 to 26 bases. Specifically, we have measured the end-to-end collision dynamics by monitoring the electron-transfer based quenching of a long-lived fluorophore (ruthenium tris(bipyridine)) covalently attached to the $3^{\prime}$ terminus of the DNA by a contact of a quencher (N-methyl- $\mathrm{N}^{\prime}$-ethyl bipyridine) attached to its $5^{\prime}$ terminus. We find that, due to the size and flexibility of the optical reporters employed experimentally, end-to-end collision dynamics exhibit little lengthdependence at length scales below 11 bases. For longer constructs, however, the end-to-end collision rate exhibits a power-law relationship to polymer length with an exponent of $-3.49 \pm 0.13$. This represents a significantly stronger length-dependence than observed experimentally for unstructured polypeptides or predicted by polymer scaling arguments. Simulations indicate, however, that the larger exponent stems from the non-trivial effects of electrostatic repulsion in these rather short, highly charged polymers. Finally, we have found that the end-to-end collision rate also depends linearly on solvent viscosity with an experimentally significant, non-zero intercept that is independent of chain length, an observation that sheds new light on the origins of the "internal friction" observed in the dynamics of many polymer systems.

\section{P480}

Synthesis, structure and DNA cleavage reactivity of iron(III) complexes supported by $\mathrm{N}_{3} \mathrm{O}$-type tripodal ligands

Hung Kay Lee*, Yee-Lok Wong, Chun-Yin Mak

Department of Chemistry, The Chinese University of Hong Kong, Shatin, New Territories, Hong Kong SAR, People's Republic of China. hklee@cuhk.edu.hk

Mononuclear iron(III) complexes $\mathbf{1}-\mathbf{3}$ supported by $\mathrm{N}_{3} \mathrm{O}$-type tripodal tetradentate ligands $\mathrm{L}^{n}(n=\mathbf{1}-\mathbf{3})$ have been prepared by treating
$\mathrm{FeCl}_{3} \cdot 6 \mathrm{H}_{2} \mathrm{O}$ with $\mathrm{HL}^{n}$ in boiling methanol. Single-crystal X-ray analysis revealed that the $\mathrm{Fe}$ (III) center in complexes 1-3 exhibits a distorted octahedral geometry. The reactivity of the complexes toward DNA cleavage has been examined. Preliminary results of our studies have shown that $\left[\mathrm{Fe}\left(\mathrm{L}^{1}\right) \mathrm{Cl}_{2}\right](\mathbf{1})$ promoted cleavage of supercoiled plasmid DNA [pGEM-3Zf(+), pUC18 and pBK-CMV] to linear forms in Tris buffer solutions, $\mathrm{pH} 7.4$, in the presence of $\mathrm{H}_{2} \mathrm{O}_{2}$ at $25^{\circ} \mathrm{C}$.

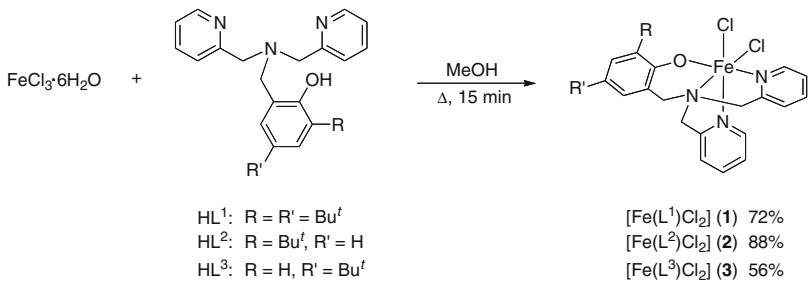

Acknowledgments: This work was supported by a Direct Grant (Project ID: 2060300) of The Chinese University of Hong Kong.

\section{P481}

Formation of a supramolecular trigonal prism by self-assembly of linear tetrakis $\left(\mathrm{Zn}^{2+}\right.$-cyclen) with trithiocyanurate in aqueous solution and its complexation with DNA (Cyclen $=1,4,7$, 10-tetraazacyclododecane) Mohd Zulkefeli ${ }^{1,2}$, Shin Aoki ${ }^{1,3}$

${ }^{1}$ Faculty of Pharmaceutical Sciences, Tokyo University of Science, Noda 278-8510, Japan,

${ }^{2}$ Faculty of Pharmacy, Universiti Teknologi MARA, Shah Alam 40450, Malaysia,

${ }^{3}$ Center for Drug Delivery Research, Tokyo University of Science, Noda 278-8510, Japan.mzmj@rs.noda.tus.ac.jp

A new supramolecular complex having a trigonal prism outfigure, $(p$, $\left.p, p-\mathrm{Zn}_{4} \mathrm{~L}\right) 3-\left(\mathrm{TCA}^{3-}\right)_{4}$, was synthesized by $3: 4$ self-assembly of linear tetrakis $\left(\mathrm{Zn}^{2+}\right.$-cyclen) complex $\left(p, p, p-\mathrm{Zn}_{4} \mathrm{~L}\right)$ and trianionic trithiocyanurate (TCA3-) in aqueous solution (cyclen $=1,4,7,10$ tetraazacyclododecane). It was found that the trigonal prism is very stable in aqueous solution at neutral $\mathrm{pH}$ in the presence of $\mathrm{Zn} 2+-$ binding anions such as phosphates dianions, as confirmed by ${ }^{1} \mathrm{H}$ NMR titration, potentiometric $\mathrm{pH}$ and UV titrations. The interaction of the polycationic trigonal prism with DNA will be presented.

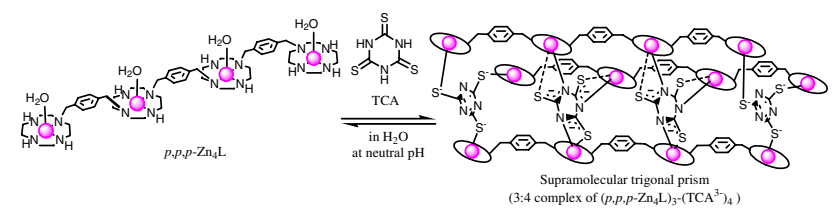

